\title{
Pengaruh Model Outdoor Learning terhadap Pemahaman Sejarah Mahasiswa Pendidikan Sejarah
}

\author{
Nilan Loliyana ${ }^{1}$, Geraldius Maria Sukamto ${ }^{1}$, Endang Sri Andayani ${ }^{1}$ \\ ${ }^{1}$ Pendidikan Sejarah-Universitas Negeri Malang
}

\section{INFO ARTIKEL}

\section{Riwayat Artikel:}

Diterima: 01-04-2019

Disetujui: 25-06-2019

Kata kunci:
outdoor learning;
historical understanding;
history student;
outdoor learning;
pemahaman sejarah;
mahasiswa sejarah

Alamat Korespondensi:

Nilan Loliyana

Pendidikan Sejarah

Universitas Negeri Malang

Jalan Semarang 5 Malang

E-mail: nilansenavia@gmail.com

\section{ABSTRAK}

\begin{abstract}
The purpose of this study was to determine the effect of the outdoor learning models on the historical understanding of 2018 generation students of State University of Malang. This study connects nature and historical material as a source of student learning. The results showed the acquisition of experimental class post-test values using the outdoor learning model was higher when compared to the control class using conventional models. The average value of students in the control class is 42.35 while in the experimental class is 68.62. Based on these results, it can be concluded that the model of outdoor learning is classified as feasible and well used in the process to improve historical understanding.
\end{abstract}

\begin{abstract}
Abstrak: Tujuan penelitian ini untuk mengetahui pengaruh model pembelajaran outdoor learning terhadap pemahaman sejarah mahasiswa sejarah angkatan tahun 2018 Universitas Negeri Malang. Penelitian ini menghubungkan alam dan materi sejarah sebagai sumber belajar mahasiswa. Hasil penelitian menunjukkan perolehan nilai posttes kelas eksperimen dengan menggunakan model outdoor learning lebih tinggi jika dibandingkan kelas kontrol dengan menggunakan model konvensional. Nilai rata-rata mahasiswa pada kelas kontrol 42.35, sedangkan pada kelas eksperimen 68.62. Berdasarkan hasil tersebut, dapat disimpulkan bahwa model pembelajaran outdoor learning tergolong layak dan dan baik digunakan dalam proses untuk meningkatkan pemahaman sejarah.
\end{abstract}

Menghadapi era modern yang terus berkembang, penyelenggaraan pendidikan sangat dibutuhkan guna mengembangkan potensi akademik mahasiswa. Hal tersebut dilakukan dengan tujuan menghasilkan generasi yang berkualitas dan berguna bagi nusa serta bangsa. Namun, pada kenyataannya tidak mudah menghasilkan generasi yang berkualitas. Terlebih lagi, setiap generasi memiliki karakter sikap, perilaku, dan pemahaman yang berbeda sesuai dengan budaya yang berkembang di zamannya. Saat ini perguruan tinggi berada pada tahap mendidik mahasiswa generasi (Martin \& Tulgan, 2002) mendefinisikan generasi Z sebagai generasi yang memiliki karakter kekinian karena lebih menikmati budaya manusia masa kini. Hal ini disebabkan sejak kecil mereka sudah mengenal sarana teknologi, seperti gadget. Secara tidak langsung pengenalan teknologi canggih di usia dini memengaruhi kepribadian para mahasiswa. Dampaknya, mereka cenderung tidak menghargai proses karena ingin serba instan (Rofi'udin, 2017). Keinginan mahasiswa generasi $\mathrm{Z}$ dalam melakukan dan memperoleh sesuatu dengan cepat memicu fenomena pengikisan karakter luhur sebagai intelektual muda di perguruan tinggi. Dengan demikian, dunia pendidikan harus dapat memahami perubahan karakteristik subjek belajar mahasiswa. Fenomena tersebut ditanggapi oleh Universitas Negeri Malang dengan menerapkan kurikulum belajar berbasis kehidupan dalam rangka menyesuaikan kapabilitas mahasiswa dengan era kekinian.

Menurut (Rofi'udin, 2017) sistem belajar berbasis kehidupan adalah sistem belajar yang menggunakan lingkungan alam kehidupannya menjadi sumber belajar yang membuka peluang untuk mengembangkan kemampuan dan kapabilitas mahasiswa generasi sekarang. (Brown, 2001) juga menjelaskan bahwa peserta didik di Skotlandia harus mencakup peluang untuk serangkaian pengalaman belajar di lingkungan alam yang direncanakan dan berkualitas, kurikulum belajar di lingkungan alam dirancang untuk meringankan beban kerja guru dan mempermudah peserta didik dalam mengikuti pembelajaran. Butuhnya berbagai model pembelajaran untuk mengenali tingkah laku dan perubahan kebutuhan yang lain (Lawton, 2017). Hal ini dianggap penting karena dalam rangka meningkatkan, memperbaiki kurikulum dan mendesain ulang pendidikan secara keseluruhan. Apabila model konvensional ceramah tersebut masih diterapkan pada matakuliah pengantar ilmu sejarah, dikawatirkan akan berdampak pada kurangnya pemahaman sejarah. Matakuliah pengantar ilmu sejarah merupakan matakuliah wajib yang harus ditempuh oleh mahasiswa sejarah. Hal ini karena matakuliah pengantar sejarah merupakan pengantar awal 
bagi mahasiswa sejarah dalam mempelajari ilmu-ilmu sejarah selanjutnya. Teori behavioristik menurut Skinner merupakan tentang stimulus respons yang menyatakan bahwa reinforcement (penguatan) adalah faktor penting dalam belajar. Belajar merupakan perubahan yang ditunjukkan dari perilaku akibat dari interaksi antara stimulus dan respon (Soesilo, 2015). Dalam proses pembelajaran, teori ini memandang bahwa tingkah laku mahasiswa sebagai respons atau reaksi dari stimulus yang diberikan oleh dosen. Menurut (Sani, Manurung, \& Suswanto, 2018) menyatakan bahwa model belajar adalah susunan konseptual yang terdiri dari pola prosedur sistematik yang disusun berdasarkan pada teori dan diaplikasikan dalam menyusun proses belajar mengajar untuk mencapai orientasi pembelajaran.

Alternatif pilihan peneliti yakni menerapkan model pembelajaran Outdoor learning yang dapat menjadi perangsang pemahaman belajar mahasiswa dalam menerima pembelajaran. Ranah kognitif berkaitan dengan hasil belajar kognitif yang ditinjau berdasarkan taksonomi Bloom yang direvisi oleh (Anderson, 2001) yang ditunjukkan dengan kemampuan remember atau mengingat $\left(\mathrm{C}_{1}\right)$, understand atau memahami $\left(\mathrm{C}_{2}\right)$, apply atau menerapkan $\left(\mathrm{C}_{3}\right)$, analyze atau menganalisis $\left(\mathrm{C}_{4}\right)$, evaluate atau menilai $\left(\mathrm{C}_{5}\right)$, create atau mencipta $\left(\mathrm{C}_{6}\right)$. Outdoor learning sudah diaplikasikan di berbagai negara, sebut saja United Kingdom, Australia, Jerman, Amerika Serikat, dan Indonesia (Sumarmi, Sejati, \& Ruja, 2016). Hal ini sependapat dengan (Rickinson, et al., 2004) yang menjelaskan tentang aktivitas belajar di luar ruangan adalah aktivitas belajar untuk mendapatkan hal baru dan semangat baru dan mengasah kemampuan, pemahaman mahasiswa. Pembelajaran Outdoor learning banyak memberikan ruang gerak bagi mahasiswa untuk dapat mengenali objek kajian secara langsung merasa senang ketika melakukan aktivitas belajar yang berpengaruh terhadap pemahaman mahasiswa (Crismono \& Prima, 2017). Pengertian pemahaman menurut adalah membangkitkan arti lisan, tulisan, dan gambar melalui interpretasi, pemberian contoh, mengelompokkan, inferensi, membandingkan, meringkas, menjelaskan dan merangkum. Jadi, memahami merupakan mampu memandang, melihatnya, mengerti dari sudut pandang yang luas.

Pembelajaran outdoor learning mempunyai nilai yang baik terhadap pemahaman mahasiswa, karena proses pembelajaran di luar kelas (outdoor learning) mampu memberikan pengalaman secara langsung kepada mahasiswa. Outdoor Learning membuat mahasiswa menemukan inspirasi dan pemahaman dalam pembelajaran (Salam, 2017). Pengertian pemahaman menurut (Anderson, \& Kratwolh 2001) adalah membangkitkan arti lisan, tulisan, dan gambar melalui interpretasi, pemberian contoh, mengelompokkan, inferensi, membandingkan, meringkas, menjelaskan dan merangkum. Jadi, memahami merupakan mampu memandang, melihatnya, mengerti dari sudut pandang yang luas. Selain itu, menurut (Rifa'i, 2017) pengertian pemahaman merupakan perolehan dari aktivitas pembelajaran, contohnya peserta didik dapat mengungkapkan dengan kata-katanya sendiri atas apa yang dilihat, didengar atau yang dibacanya. Selain itu, siswa juga dapat memberikan contoh lain dicontohkan dan menerapkan petunjuk pada kasus lain. Dari pengertian di atas dapat diartikan bahwa pemahaman adalah kemampuan seseorang untuk mengerti atau memahami sesuatu setelah sesuatu itu diketahui, dikenal, dan diingat.

\section{METODE}

Metode dalam penelitian ini menggunakan pretest posttest experimen \& control group design. Penelitian ini terdiri dari dua kelas, yaitu kelas kontrol dan kelas eksperimen. Kelas eksperimen menggunakan model belajar outdoor learning, sedangkan kelas kontrol menggunakan model konvensional. Pretest diberikan sebelum perlakuan sedangkan posttest diberikan setelah perlakuan. Penelitian ini mempunyai tujuan untuk menjelaskan tentang Pengaruh Model Pembelajaran Outdoor Learning terhadap Pemahaman Sejarah Mahasiswa Sejarah Angkatan 2018 Universitas Negeri Malang. Data dikumpulkan dengan menggunakan tes yang diperoleh dari mahasiswa sejarah. Rumus yang digunakan untuk mencari perolehan skor hasil tes pilihan ganda dalam penelitian ini yaitu.

Keterangan:

$$
\mathrm{S}=\frac{B}{N} x 100
$$

$\mathrm{S}=$ Skor

$\mathrm{B}=$ Jumlah jawaban benar

$\mathrm{N}=$ Jumlah soal (Arifin, 2014)

\section{HASIL}

Penelitian yang dihasilkan dalam penelitian ini yaitu nilai pretest dan posttest pemahaman sejarah mahasiswa sejarah angkatan 2018 Universitas Negeri Malang. Berikut merupakan hasil dari nilai pretest dan posttest pemahaman sejarah dalam penelitian ini. Pretest dilaksanakan sebelum proses perlakuan pada kelompok kontrol dan pada kelompok eksperimen. Pretest ini dilakukan dalam rangka untuk mengetahui kemampuan awal mahasiswa baik mahasiswa kelas kontrol maupun kelas eksperimen. Hasil pretest pada kelas kontrol dan kelas eksperimen dapat dilihat pada tabel 1. Data posttest pemahaman sejarah mahasiswa kelas eksperimen dan kelas kontrol disajikan pada tabel 2.

Pada tabel 1 menunjukkan frekuensi distribusi pretest pemahaman sejarah mahasiswa pada kelas kontrol. Nilai ratarata mahasiswa pada kelas kontrol adalah 37.98, sedangkan nilai rata-rata mahasiswa pada kelas eksperimen adalah 54.87. Jadi, pada kedua kelas tersebut terdapat selisih 16,89 sehingga dapat dikatakan bahwa hasil nilai pretest pemahaman sejarah di kelas kontrol dan eksperimen cukup terlihat perbedaannya. Posttest pemahaman sejarah mahasiswa merupakan nilai yang diperoleh 
dari hasil tes pemahaman sejarah pada kelas eksperimen setelah diberikan perlakuan menggunakan model belajar outdoor learning yang diujikan dan kelas kontrol yang tidak diberikan perlakuan. Posttest dilakukan untuk mengetahui kemampuan mahasiswa setelah diberikan perlakuan. Berikut merupakan data posttest pemahaman sejarah mahasiswa kelas eksperimen dan kelas kontrol.

Pada tabel 2menunjukkan frekuensi distribusi posttest pemahaman sejarah mahasiswa pada kelas kontrol dan eksperimen. Nilai rata-rata mahasiswa pada kelas kontrol 42.35, sedangkan pada kelas eksperimen 68.62. Jadi, pada kedua kelas tersebut terdapat selisih 26.27 sehingga dapat dikatakan bahwa hasil nilai posttest pemahaman sejarah di kelas kontrol dan eksperimen sangat berbeda.

Tabel 1. Hasil Pretest pada Kelas Kontrol dan Kelas Eksperimen

\begin{tabular}{cccccc}
\hline \multirow{2}{*}{ Nilai } & \multirow{2}{*}{ Kriteria } & \multicolumn{2}{c}{ Kelompok Kontrol } & \multicolumn{2}{c}{ Kelompok Eksperimen } \\
\cline { 3 - 6 } & & Frekuensi & \% & Frekuensi & $\%$ \\
\hline $0-20$ & Sangat Rendah & 1 & $3 \%$ & 0 & $0 \%$ \\
\hline $21-40$ & Rendah & 18 & $56 \%$ & 2 & $6 \%$ \\
\hline $41-60$ & Cukup & 13 & $41 \%$ & 22 & $69 \%$ \\
\hline $61-80$ & Tinggi & 0 & 0 & 7 & $22 \%$ \\
\hline $81-100$ & Sangat Tinggi & 0 & 0 & 1 & $3 \%$ \\
\hline Total & & 32 & 100 & 32 & 100 \\
\hline Mean & & & 37.98 & & 54.87 \\
\hline
\end{tabular}

Tabel 2. Data Posttest Pemahaman Sejarah Mahasiswa Kelas Eksperimen dan Kelas Kontrol

\begin{tabular}{cccccc}
\hline \multirow{2}{*}{ Nilai } & \multirow{2}{*}{ Kriteria } & \multicolumn{2}{c}{ Kelompok Kontrol } & \multicolumn{2}{c}{ Kelompok Eksperimen } \\
\cline { 3 - 6 } & & Frekuensi & $\%$ & Frekuensi & \% \\
\hline $0-20$ & Sangat Rendah & 1 & $3 \%$ & 0 & $0 \%$ \\
\hline $21-40$ & Rendah & 11 & $34 \%$ & 0 & $0 \%$ \\
\hline $41-60$ & Cukup & 20 & $63 \%$ & 6 & $19 \%$ \\
\hline $61-80$ & Tinggi & 0 & 0 & 23 & $72 \%$ \\
\hline $81-100$ & Sangat Tinggi & 0 & 0 & 3 & $9 \%$ \\
\hline Total & & 32 & 100 & 32 & 100 \\
\hline Mean & & 42.35 & & 68.62 \\
\hline
\end{tabular}

\section{PEMBAHASAN}

Pemahaman dalam penelitian ini menekankan pada pemahaman dalam pembelajaran sejarah yang bukan hanya sekedar mengetahui kumpulan bangunan-bangunan peninggalan sejarah masa lalu yang tidak memiliki makna. Peninggalan masa lalu hanya dapat dipahami dengan konteks masa kini dan sebaliknya memahami masa kini hanya dengan sudut pandang masa lalu (Carr, 2014). Peristiwa masa lalu memiliki makna terhadap kehidupan masa kini. Indonesia memiliki sejarah yang panjang sebagai negara yang pernah dijajah oleh Belanda. Kenangan akan kejayaan masa lalu begitu membekas di hati masyarakat Indonesia (Anderson, 2001). Bangunan kolonial inilah yang menjadi sumber-sumber belajar mahasiswa sejarah. Hal ini sependapat dengan (Ali, 2005) yang menyatakan bahwa beribu-ribu peninggalan sejarah yang berada di Indonesia dapat digunakan sebagai sumber belajar. Dengan menggunakan model pembelajaran outdoor learning mahasiswa dapat memahami dan mengerti makna dari sumber-sumber sejarah dengan cara belajar pada objek secara langsung.

Penerapan model pembelajaran outdoor learning pada kelas eksperimen memiliki pengaruh terhadap peningkatan pemahaman sejarah mahasiswa sejarah secara signifikan. Hal ini sependapat dengan (Dipo \& Samsudin, 2016) yang menyatakan bahwa model pembelajaran yang digunakan sedikit banyak menentukan pemahaman mahasiswa dan memengaruhi aktivitas belajar. Keadaan di lapangan menunjukkan dengan penerapan outdoor learning mahasiswa lebih menikmati pembelajaran seperti, mahasiswa lebih aktif dalam bertanya tentang bangunan-bangunan kolonial kepada ahlinya, mahasiswa dapat lebih memaknai sumber-sumber belajar, mahasiswa dapat menyentuh langsung bangunan-bangunan kolonial yang digunakan sebagai sumber belajar dan mahasiswa dapat mengambil gambar serta video untuk dijadikan bahan laporan pembelajaran. Dengan demikian, kegiatan belajar mahasiswa dapat lebih mudah memaknai dan mengerti materi pembelajaran yang bersifat abstrak menjadi gambaran yang lebih nyata. Hal ini sependapat dengan (Marijan, 2012) menjelaskan bahwa pembelajaran berbasis lingkungan memberikan beberapa keuntungan, antara lain (1) aktivitas belajar lebih dapat menarik perhatian mahasiswa; (2) lingkungan alam memiliki banyak hal yang dapat digunakan sebagai sumber belajar; (3) kegiatan belajar lebih bermakna; (4) aktivitas mahasiswa lebih interaktif; terjadi pembentukan karakter siswa. Selain itu, (Rifa'i, 2017) juga menyatakan bahwa keuntungan model pembelajaran outdoor learning adalah kegiatan belajar lebih bermakna sebab mahasiswa diperlihatkan dengan situasi dan keadaan nyata dan kegiatan belajar mahasiswa juga lebih komprehensif sebab dapat dilakukan dengan melihat, mengamati, mendengarkan, bertanya, wawancara, merekam dan lain sebagainya. 
Pembelajaran outdoor learning tidak hanya secara individu, namun dapat melakukan diskusi antar teman dan dosen (Nugroho \& Hanik, 2016). Dalam hal ini mahasiswa sejarah sangat dilibatkan langsung dalam memperoleh dan menemukan pengetahuan secara langsung sehingga materi yang didapatkan pada proses pembelajaran dapat tersimpan lebih lama. Selain itu, terdapat kendala yang harus dihadapi yakni tentang agenda yang terjadwal hingga resiko pembelajaran di luar (Gibson \& Haynes, 2008). Pada kelas kontrol pemahaman sejarah menggunakan model pembelajaran konvensional sehingga mahasiswa tidak melakukan pembelajaran di luar kelas atau outdoor learning. Mahasiswa kelas kontrol menggali dan memahami materi melalui beberapa penjelasan dari dosen yaitu, dengan melihat gambar-gambar yang ditayangkan melalui power point tentang sumber-sumber sejarah dan periodisasi sejarah, menjawab pertanyaan yang diberikan dosen, mencatat materi-materi yang ditayangkan melalui power point. Selain itu, dosen memberikan buku-buku mengenai materi sumber-sumber sejarah sejumlah empat buku untuk dibaca secara bergantian. Dengan begitu mahasiswa hanya dominan membaca dan mendengarkan dosen saja dan kurang memahami makna dari bacaan materi yang dibahas.

Perbedaan pada pemahaman belajar mahasiswa menggunakan model pembelajaran outdoor learning disebabkan adanya tour guide yang langsung memberikan deskripsi dari bangunan-bangunan kolonial dan antusias mahasiswa untuk belajar langsung pada objek belajar. Selain itu, didukung dengan buku-buku yang berkaitan dengan materi-materi tentang sumbersumber sejarah. Hal ini sependapat dengan (Prihantoro, 2010) yang menyatakan bahwa dengan outdoor learning mahasiswa sejarah dapat lebih mengerti mengenai makna materi yang dipelajari karena mahasiswa dilibatkan langsung secara holistik baik aspek fisik, emosional, dan intelektualnya. Dengan demikian, pemahaman mahasiswa pada hal yang masih abstrak menjadi jelas untuk dipahami dan menjadi konkret pada saat pembelajaran. Kemudian, dengan pemahaman sejarah yang baik melalui model pembelajaran outdoor learning mahasiswa dapat dengan mudah mengerti materi pembelajaran. Sehingga hasil belajarpun meningkat dilihat dari posttest mahasiswa. Hal ini sesuai dengan pendapat (Sayekti, Suwono, \& Sueb, 2017) yang mengungkapkan besarnya sumbangsih media atau model belajar terhadap kegiatan pembelajaran sehingga dapat memfasilitasi siswa untuk mengembangkan kemampuannya. Dengan antusiasnya mahasiswa dalam mengikuti pembelajaran dapat dikatakan mahasiswa mulai memahami materi sehingga semua dapat terlihat dari perbedaan hasilnya.

Penelitian ini sesuai dengan penelitian yang dilakukan oleh orang lain. Pada penelitian yang lain yang dilakukan oleh (Dietz, 2002) yang menyimpulkan bahwa penggunaan model pembelajaran di luar kelas atau outdoor learning sangat berpengaruh terhadap pemahaman dan daya ingat belajar siswa. Ini berarti model pembelajaran outdoor learning sangat berpengaruh terhadap pemahaman belajar, perbedaan dalam penelitian ini yaitu pada subjek penelitiannya. Hal ini sependapat dengan penelitian yang dilakukan (Karmila, 2016) yang menyimpulkan cara untuk menumbuhkan hasil belajar dan pemahaman siswa dapat menggunakan model pembelajaran outdoor learning. Penggunaan model pembelajaran outdoor learning sangat menunjang pembelajaran yang ingin meningkatkan pemahaman-pemahaman belajar siswa. Penggunaan model pembelajaran outdoor learning telah diteliti oleh beberapa peneliti dan sukses dalam memperbaiki pembelajaran.

Berdasarkan hasil uji-t memperlihatkan jika model pembelajaran outdoor learning dapat berpengaruh terhadap pemahaman sejarah mahasiswa. Hal ini sependapat dengan (Kurniasih, 2015) yang mengungkapkan pendidikan yang dilakukan di luar kelas mengacu kepada pengalaman belajar dan pendidikan alam yang sangat berpengaruh pada pemahaman mahasiswa. Hal ini dibuktikan model pembelajaran outdoor learning secara signifikan lebih berpotensi meningkatkan pemahaman sejarah dibandingkan model pembelajaran konvensional. Hasil uji Independent Sample t-test menunjukkan bahwa sig. (2-tailed) yaitu $0.001<0,05$, maka $\mathrm{H}_{0}$ ditolak. Oleh karena itu, dapat diambil kesimpulan bahwa ada pengaruh model pembelajaran outdoor learning terhadap pemahaman belajar sejarah mahasiswa jurusan sejarah angkatan 2018 Universitas Negeri Malang.

\section{SIMPULAN}

Berdasarkan hasil analisis data dan tes pemahaman sejarah dapat disimpulkan bahwa model pembelajaran outdoor learning berpengaruh baik terhadap pemahaman sejarah mahasiswa sejarah angkatan 2018 Universitas Negeri Malang. Hal tersebut dikarenakan dengan penggunaan model pembelajaran outdoor learning mahasiswa lebih mudah memahami materi pembelajaran yang bersifat abstrak menjadi gambaran yang lebih nyata.

\section{DAFTAR RUJUKAN}

Ali, M. (2005). Pengantar Ilmu Sejarah Indonesia. Yogyakarta: LKIS Yogyakarta.

Anderson, L. R., \& K. D. (2001). A Taxonomy for Learning, Teaching, and Assessing: A Refision Bloom 's Taxonomy Educational Objective. New York: Longman.

Brown, H. D. (2001). Teaching by Principle An Interactive Approach to Language Pedagogy. San Fransisco.

Carr, E. (2014). Apa Itu Sejarah. Jakarta: Komunitas Bambu.

Crismono, P. C. (2017). Pengaruh Outdoor Learning terhadap Kemampuan Berpikir Kritis Matematis Siswa. Jurnal Pendidikan Matematika dan Sains, 5(2), 106-113.

Dietz, K. (2002). Influence of Teaching in an Outdoor Classroom on Kindergarten Children's Comprehension and Recall of A Science Lesson.

Dipo, M., \& Samsudin, I. (2016). Pengaruh Pembelajaran Model Observasi Lapangan (Outdoor Study) dan Pembelajaran Inquiry terhadap Hasil Belajar Mata Pelajaran Sosiologi Siswa IPS SMA Negeri 3 Probolinggo. Jurnal Penelitian dan Pendidikan IPS (JPPI), 10(2), 261-276. 
Gibson, S., \& Haynes, J. (2008). in S. Gibson \& J. Haynes (ed.). Perspectives on Participation and Inclusion: Engaging Education: Continuum, 1-16.

Karmila. (2016). Pengaruh Penerapan Metode Outdoor Learning Berbasis Kelompok terhadap Hasil Belajar IPS di SDN. Journal of Educational Science and Technology, 2(April), 26-32.

Kurniasih, A., Darsiharjo., \& Maryani, E. (2015). Penggunaan Metode Pembelajaran Outdoor Study terhadap Pemahaman Konsep Pelestarian Lingkungan Hidup Peserta Didik di MTsN Singaparna. Jurnal Pendidikan Geografi, 15(1), 9-16. http://dx.doi.org/10.17509/gea.v15i1.4180

Lawton, M. (2017). Employers' Perspectives on Maximising Undergraduate Student Learning from the Outdoor Education Centre Work Placement. Journal of Hospitality, Leisure, Sport \& Tourism Education, 21(13), 1-12 https://doi.org/10.1016/j.jhlste.2017.05.001

Marijan. (2012). Pemanfaatan Lingkungan Sekitar Sekolah sebagai Sumber Belajar Keanekaragaman Tumbuhan bagi Peserta Didik Kelas VII Semester 2 SMP Negeri 5 Wates Kulon Progo. In Prosiding Seminar Nasional Penelitian, Pendidikan dan Penerapan MIPA, Fakultas MIPA UNY (p. 7). Yogyakarta: Fakultas MIPA UNY.

Martin, C. A., \& Tulgan, B. (2002). Managing The Generation Mix: From Collision to Collaboration. Human Resource Development.

Nugroho, A. A., \& Hanik, N. R. (2016). Implementasi Outdoor Learning untuk Meningkatkan Hasil Belajar Kognitif Mahasiswa pada Matakuliah Sistematika Tumbuhan Tinggi. Bioedukasi: Jurnal Pendidikan Biologi, 9(1), 41-44. https://doi.org/10.20961/bioedukasi-uns.v9i1.3884

Prihantoro, I. (2010). Metode Pembelajaran Outdoor Study. Jakarta: PT. Gramedia.

Rickinson, M., Dillon, J., Teamey, K., Morris, M., Choi, M. Y., Sanders, D., \& Benefield, P. (2004). March 2004. National Foundation for Educational Research and King's College London, (March), 1-62.

Rifa'i, S. (2017). Media Pengajaran. Bandung: Sinar Baru Algensindo.

Rofi'udin. (2017). Kurikulum Transdisipliner dan Belajar Berbasis Kehidupan. Malang: Universitas Negeri Malang.

Salam, R. (2017). Implementation of Outdoor Learning Method in Improving Skills of Writing. International Journal of Social Science and Humanities Research, 5(3), 504-512.

Sani, R. A., Manurung, S. R., \& Suswanto, H. (2018). Penelitian Pendidikan. Tangerang: Tira Smart.

Sayekti, E., Suwono, H., Sueb. (2017). Pengaruh Model Pembelajaran Inkuiri Sains Berbantuan Mind Maping terhadap Hasil Belajar Biologi Siswa Kelas X SMA. Jurnal Pendidikan Teori, Penelitian, dan Pengembangan., 2 (4), 550-555.

Soesilo. (2015). Teori dan Pendekatan Belajar. Yogyakarta: Ombak.

Sumarmi., Sejati, A. E., \& Ruja, I. N. (2016). Pengaruh Metode Pembelajaran Outdoor Study terhadap Kemampuan Menulis Karya Ilmiah Geografi SMA. Jurnal Pendidikan: Teori, Penelitian, dan Pengembangan, 1(2), 17-19. 